\title{
Holger Højlund
}

\section{Den frit vælgende ældre}

I de senere år er frit valg blevet præsenteret som den foretrukne vej til markedsgørelse af den offentlige sektor. Frit valg er samtidig præsenteret som borgernes mulighed for at blive involveret i velfærdens beslutningstagning. En nærmere analyse af en lovreform på ældreområdet viser, at frit valg åbner for modsatrettede tendenser i rolleforventningerne til ældregruppen. Det handler om betingelserne for inklusion af de ældre samt om præmisserne for de interne differentieringer på området. Med afsæt i den organisatoriske del af systemteorien vil artiklen undersøge, hvordan frit valg skaber spændinger i velfærdens beslutningsgrundlag. Som det vigtigste mellem beslutninger i hverdagens konkrete velfærdsudøvelse og beslutninger i de administrative systemer omkring velfærden. 


\section{Frihedens politik}

Friheden til selv at vælge er omdrejningspunkt for regeringens politik. Med reformprogrammet velfxrd og valgfrihed igangsættes en proces, som vil øge borgernes valgfrihed betydeligt (Regeringen 2002b: forord).

$\mathrm{I}$ starten af 2001 lancerede den nyligt tiltrådte venstre-konservative regering et stort anlagt moderniseringsprogram, som fik eget kontor i Finansministeriet. Moderniseringsprogrammet havde overskriften "Med borgeren ved roret" (Regeringen 2002a) og var hovedhjørnesten i en strategi for fornyelse af den offentlige sektor. To principper blev fremhævet for fornyelsesarbejdet: Dels skulle den offentlige sektor gøres enklere og mere effektiv, dels skulle hensynet til borgerne være i centrum. En lang række borgerrelaterede initiativer blev sat i værk. Der blev indført fleksibel barselsorlov, tilskud til pasning af egne børn, udvidet frit sygehusvalg, privat hjemmesygepleje og frit valg af a-kasse. Modernisering handlede tydeligvis om at skabe valgmuligheder. Regeringen talte om at skabe en mere borgernær offentlig sektor (Regeringen 2003). Der var lovændringer på samtlige kerneområder: børn, sundhed, ældre, det sociale område og arbejdsmarkedet. Regeringen sigtede bredt. Nu skulle borgerne have indflydelse på eget liv. Som det blev formuleret, ville en øget involvering medføre “(...) en styrkelse af borgerens stilling i forhold til det offentlige og være et værn mod den afmagt og umyndiggørelse, som borgeren til tider kan opleve“ (Regeringen 2002a:4).

Denne artikel vil fokusere på et afgrænset reforminitiativ i regeringens moderniseringsprogram. Reforminitiativet er gået under navnet ældrepakken og har haft til formål at skabe marked på ældreområdet. Ikke et marked baseret på fri konkurrence, men et marked under politisk regulering.

Med ældrepakken frisættes både politiske og økonomiske logikker. Det er artiklens tese, at disse logikker holdes sammen af en ny borgerkonstruktion, den frit vælgende ældre. Intet marked for ældreydelser uden de ældre som forbrugere. Eller kan man også sige: Ingen markedsdannelse, hvis ikke de ældre tager den nye identitet på sig. De ældres velvilje er en betingelse for marked. Markedet udfoldes om dem.

Artiklen søger at vise, at den frit vælgende ældre, som nyopfunden bruger legemliggør områdets enhed: Én brugeraktør, én beslutningslogik. Dette på trods af at der stadigvæk er vigtige beslutninger, som træffes af andre. Disse beslutninger træffes af politikere, fagpersoner og eksperter. Selvom disse differentieringer er helt nødvendige for ældrehjælpen, er det frie valg gjort centralt. Artiklen afdækker denne bevægelse og viser, at det velfærdsmarked, som etableres med ældrepakken, er organiseret om mange beslutningskontekster, men med et samlende referencepunkt nemlig det frie valg.

Det er væsentligt at slå fast, at der er tale om et administrativt konstruktionsarbejde. I ældrepakken formes nye betingelser for et velfærdsområdes interne 


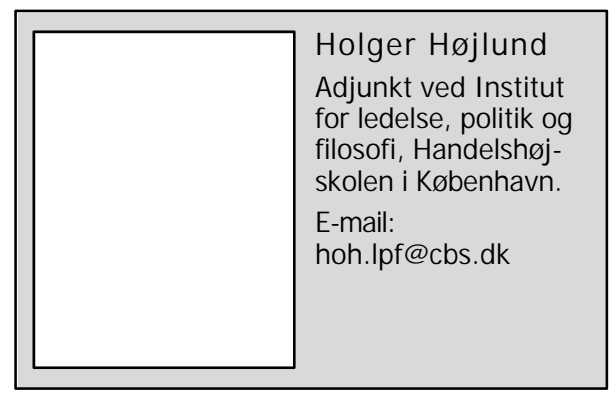

differentiering og integration. Artiklen handler om dette konstruktionsarbejde og ikke om virkeligt trufne valg eller faktiske ældre. Der er en analytisk pointe i denne tilgang. Den gør det muligt alene at fokusere på betingelser. Det handler om, hvordan samspillet mellem velfærdsstat og borgere er betinget af de brugerog borgerkategorier, der står til rådighed. Betingelserne er politisk satte, også når der er tale om nyåbnede markedsstrukturer.

Selvom det frie valg indikerer, at velfærden er blevet den enkeltes egen sag, er udfoldelsesrummet politisk defineret. Artiklen søger at afdække dennefrihedens politik. Det er tale om en ny reguleringsform, hvor gængse skel overskrides. Politikken udfoldes så at sige gennem de personkategorier, borgerne tilbydes, og når disse personkategorier samtidig er formuleret med frihedsbegreber, opstår der et særligt spil mellem frihed og politik, hvor friheden dels er politikkens andenside, dels politikkens nødvendige omdrejningspunkt. Ingen politik uden frie borgere, men heller ingen frie borgere uden for de politiske rammer. Friheden er både forudsat $\mathrm{g}$ betinget af den politiske regulering.

En vigtig side af frihedens politik handler om, at frit valg er et tilbud, der ikke kan afslås. Som borger må du tage friheden på dig, hvis du vil være med. Friheden er præmis for borgernes inklusion/eksklusion og har som sådan noget bydende over sig. Artiklen vil dyrke denne modsætning: Et frit valg, der ikke kan afslås. En frihed, der truer med at slå over sin modsætning. Rollen som frit vælgende forbruger sætter nogle ganske bestemte betingelser for, hvilke personlige egenskaber borgeren har mulighed for at bringe med sig i interaktionen med velfærdsstatens professionelle. Bag den enkle frit valgs-konstruktion gemmer sig en kompleks tilskrivning af identitet.

Det handler om forventningsstrukturer. Det handler i ældrepakken om at etablere en rollekategori, der er mere kompleks end tidligere. Betydningen af, at ældre konstrueres som frit vælgende, kan ikke undervurderes. Forventningsdannelsen stabiliseres om denne personfigur. Figuren binder sammen og understøtter en forestilling om helhed, samtidig som figuren gør differentiering mulig. Ældremarkedets beslutningstagere kan referere til den frit vælgende ældre, når de træffer deres beslutninger. 


\section{Systemteorien som optik}

Den valgte optik for analyserne er systemteoretisk. Uden at komme med længere udredninger vil jeg nævne et par konsekvenser af dette. For det første betyder det, at artiklen vil være tømt for rigtige mennesker. Her vil hverken være ældre med fysik og psyke eller plejepersonale af kød og blod. I stedet vil være personer kommunikeret frem i den velfærdsstatslige kommunikation. ${ }^{1}$

For det andet erstatter artiklen et traditionelt begreb om integration med et begrebspar om inklusion/eksklusion. Hvornår kan man tale om inklusion? Svaret er: Når mennesker gøres relevante for en velfærdsstatslig kommunikation. Det betyder, at mennesker inkluderes i velfærdsstatens organisationer ved, at eksperter kommunikerer dem i særlige personkategorier. ${ }^{2}$

For det tredje anlægger artiklen en snæver vinkel på organisationer og organisering. Analyserne handler først og fremmest ombeslutningerog beslutningspræmisser. Det vil blive vist, hvordan et program, "ældrepakken", former præmisser for beslutningstagningen på et velfærdsstatsligt område bestående af sideordnede organisationssystemer. ${ }^{3}$

For det fjerde trækker artiklen på etpolitikbegreb, der på én og samme gang er snævert og bredt. Snævert fordi politik handler om at kommunikere i én kode og om at sætte en enhed mellem væsensforskellige organisationssystemer (Luhmann 1987; 1990; 2000c), og bredt fordi politik handler om at skabe betingelser (Stäheli 1998). Som analyserne vil vise, handler politik om det politiske systems evne til at forme betingelser for bestemte systemkoblinger. Dette sker gennem programmer, som er defineret med en tilstrækkelig ubestemthed til, at beslutningssystemer kan gøre dem centrale for deres forskellige beslutningsprocesser. Samtidig må programmerne være tilstrækkeligt faste til at forme en fælles orientering i systemerne. Dette kan også formuleres som, at politisk styring handler om at sætte betingelser for et spil mellem faste og løse koblinger.

\section{At danne marked}

Der skal være en reel mulighed for at vælge mellem forskellige løsninger. Derfor vil regeringen skabe klare rammer og vilkår for at private virksomheder og frivillige organisationer i endnu højere grad inddrages i løsningen af de offentlige opgaver (Regeringen 2002a:5).

Før vi kigger på ældrepakken, er det nødvendigt at sige noget generelt om de seneste årtiers debat om markedsdannelse i den offentlige sektor. Her er det kendetegnende, at debatten har bevæget sig fra at være relativt homogen til i dag at udgøre et knudepunkt for forskellige tilgange til konkurrence. Hvor man i begyndelsen af 1990'erne næsten udelukkende diskuterede udlicitering, snakker man i dag om kombinationsløsninger. Begreber som miksstyring og quasimarked er på dagsordenen. Kontrakter, samarbejdshybrider og bestiller- 
udfører-modeller indføres til udvikling af velfærdsstaten snarere end afvikling (Greve 2004; Højlund 2004:91-164).

Hvad betyder introduktionen af de mange markedsformer i den offentlige sektor? I hvert fald giver det en fornemmelse af fortsat bevægelse. Markedsreformerne holder så at sige maskineriet i gang. At danne marked i offentlig kontekst er et pragmatisk forehavende, der både handler om konkurrence og samarbejde. Et citat fra en af debattens væsentlige aktører, Finansministeriet, illustrerer tankegangen:

Konkurrenceudsættelse er ét blandt flere mulige effektiviseringsredskaber, som den offentlige sektor kan anvende. Rigtigt anvendt er konkurrenceudsættelse et virkningsfuldt forandringsredskab, som sætter pres på og accelererer ønskede forandringer. Partnerskabet med eksterne serviceleverandører kan være et gavnligt "fremmedelement", som giver offentlige serviceproducenter inspiration til nytænkning og forandring (Finansministeriet 2000a:4).

Som det fremgår af citatet, er der flere mulige veje til reform. I det nedenstående skema er opridset to veje til velfærdsmarked.

For det første er der den markedsdannelse, som handler om at skabe konkurrence mellem organisatoriske enheder. Denne markedsdannelse kan enten være eksternt eller internt rettet. I den eksternt rettede version handler det om at skabe konkurrence mellem offentlige og private udbydere eller mellem private udbydere alene. I den internt rettede version handler det om at skabe konkurrence mellem offentlige udbydere. Dette ses f.eks., når kommuner organiserer sig $\mathrm{i}$ virksomhedsmodeller og lader institutioner kæmpe om ressourcerne.

For det andet er der den markedsdannelse, som er borgerorienteret. Er denne markedsdannelse eksternt rettet, handler det om at give brugergrupper frit valg mellem private og offentlige udbydere. Er den internt rettet handler det om at give valgmuligheder mellem offentlige udbydere.

Figur 1. Markedsdannelsens former ${ }^{4}$

\begin{tabular}{|l|l|l|}
\hline & Ekstern markedsdannelse & Intern markedsdannelse \\
\hline $\begin{array}{l}\text { Organisatorisk } \\
\text { orienteret }\end{array}$ & $\begin{array}{l}\text { - Udbud, offentligt-privat samspil } \\
\text { - Privatisering }\end{array}$ & $\begin{array}{l}\text { - Intern kontraktsyring, bestiller- } \\
\text { udfører-organisering } \\
\text { - Kvalitetsstyring, bench marking }\end{array}$ \\
\hline Borgerorienteret & - Vouchers, personlige kontrakter \\
& - Frit valg ml. offentlig og privat & - Frit valg i offentligt regi \\
\hline
\end{tabular}




\section{Opspil til ældrepakken: Kvalitetsudvikling og kritik}

Kigger man på årtiet før ældrepakken i 2001 formes nogle strukturelle præmisser for marked. På ældreområdet som på flere andre velfærdsområder gennemføres kvalitetsreformer. Det handler om at skabe den rette synlighed for marked. På sundhedsområdet igangsættes i 1993 “National strategi for kvalitetsudvikling i Sundhedsvæsenet" (Sundhedsstyrelsen 1992; 1993). På det sociale område dannes et eget "Institut for kvalitet" (Institut for Serviceudvikling 2000). I staten indstifter man sin egen kvalitetspris med hjemmeside og årlig uddeling (www.sckk; www.kvalitetsprisen.kk.dk).I flere ministerielle rapporter er kvalitetsudvikling en gennemgående referenceramme.

På ældreområdet har særligt to kvalitetsinitiativer været fremtræedende. Det ene initiativ, "fælles sprog" (Kommunernes Landsforening 1998a; 2003), er et frivilligt IT- og begrebsudviklingsprojekt udviklet $\mathrm{i}$ kommunalt regi. Det andet initiativ, "lov om kvalitetsstandarder" (LBK328; VEJ 83), er et ministerielt initiativ (se Højlund 2004:108-125).

I fælles sprog-programmet er grundkonceptet enkelt. To kataloger inddeler ældreområdets kommunikationer. I det ene katalog samles de kommunikationer, der handler om ydelser. I det andet samles de om behov. Katalogerne medtager områder fra personlig pleje over daglig husførelse til almene aktiviteter, socialt samvær og mental tilstand. Ni områder danner baggrund for en samlet funktionsvurdering, og 14 ydelseskategorier dækker plejeindsatsen. Tilsammen udgør de to kataloger et færdigt redskab. Redskabet specificerer begrebsbrug og retningslinjer for begrebsafvigelse og sikrer ældreområdet synlighed om beslutningstagningen (Højlund/Højlund 2000; Hansen/Nedung 2005).

Kigger vi herefter på det ministerielle initiativ, "Lov om kvalitetsstandarder" (LBK 328), så pålægger loven kommunerne at formulere en kvalitetsstandard for ældrepleje. Standarden skal dels danne grundlag for den serviceinformation, der produceres til borgerne, dels normere de operationelle mål, som sættes internt på området.

En kvalitetsstandard skal indeholde generel serviceinformation til borgerne om den hjælp, de kan forvente fra kommunen, hvis de får behov for personlig og praktisk hjælp m.v. Kvalitetsstandarden skal dermed indeholde en beskrivelse af det serviceniveau, som kommunalbestyrelsen træffer beslutning om. Beskrivelsen af indholdet, omfanget og udførelsen af hjælpen skal være præcis, og der skal samtidig opstilles kvalitetsmål (operationelle mål), som det efterfølgende er muligt for kommunalbestyrelsen at bedømme indsatsen efter (LBK $328 \S 2$, stk. 2).

Sammenligner man de to kvalitetsinitiativer, tager de begge udgangspunkt $i$ en tilgang, hvor det handler om at skabe tydelige beskrivelser af hjælpens indhold og udførelse. Det handler om administrativ opgradering og synliggørelse af ser- 
viceudøvelsen. Fælles sprog og standarder har til formål at sikre politikerne viden om de politiske prioriteringer og borgerne viden om, hvad de har ret til. Samtidig skal ledere og medarbejdere klædes bedre på til planlægning, hedder det. I en publikation fra Kommunernes Landsforening slås fast, at man kun kan forvente at lykkes med styringen, hvis den tager udgangspunkt " (...) i en detaljeret beskrivelse af de ydelser, der udføres, samt de krav, ydelserne skal leveoptil. En egentlig kravspecifikation" (Kommunernes Landsforening 1998b:7).

Kigger man lidt bag ældreområdets kvalitetsreformer, ser man et særligt ideal om synlighed. For begge reformer gælder, at standarder og fast begrebsbrug skal skabe gennemsigtighed og sammenlignelighed.

Sådan er idealet. I praksis har erfaringerne været mere blandede. Det omfattende reformarbejde er ikke forløbet uden konflikter. Flere medarbejdergrupper har følt deres faglighed truet. Særligt de medarbejdere, der står med den konkrete velfærdsudøvelse, har peget på kvalitetsteknologiens opsplittende effekter.

Vi professionelle kan ikke gøre os håb om at bidrage til kvalitetsudviklingen, før vi forholder os kritisk til Fælles sprog og til ydelser baseret på minutkalkuler. Det hører ganske enkelt ikke hjemme i omsorgsarbejdet! (Petersen/Schmidt 2003:174).

Citatet giver indtryk af kritikken. En central indvending har handlet om tab af helhed. Bag denne kritik ligger en oplevelse af, at den politisk-administrative styring er blevet opprioriteret på bekostning af hjælpeudøvelsen. ${ }^{5}$

Omkring årtusindeskiftet var denne type kritik særlig tydelig. I en ophedet debat om standarder og bureaukrati blev kommunerne kritiseret for systemtankegang og optællingsmentalitet. Kritikken blev fremført på en række ældrehøringer arrangeret af Socialministeriet. Her var ældreområdets vigtigste aktører samlet til debat. Ældrebrugere sad sammen med pårørende, politikere, fagpersoner og andre interessenter. Temaet var ældreområdets fremtid. Flere deltagere rettede en kraftig kritik mod ældreområdet. De ældre var sat uden for indflydelse, lød kritikken. Hjælpen var blevet en standardvare, som ikke længere tog udgangspunkt $\mathrm{i}$ hverdagen, men i stedet $\mathrm{i}$ minutiøse administrative programmer (la Cour/Højlund 2001; Højlund 2003:285-286). ${ }^{6}$

Set over en bred kam har de seneste års kritik haft det fælles udgangspunkt at spørge til ældreområdets kvalitetsudvikling fra de ældres perspektiv. Fra flere sider er spurgt, om de ældres interesser, krav og forventninger er blevet sat til side til fordel for standardløsninger. Overskriften på en konference fra årtusindeskiftet er sigende: "Ældreomsorg management eller menneskelighed?" (Videnscenter på ældreområdet 2001).

Et vigtigt budskab har været, at standarder og informationsteknologiske landevindinger har skabt sikkerhed $\mathrm{i}$ administrationen, men ikke i den praktiske hjælp hvor brugen af kvalitetsteknologi har haft bivirkninger i form af min- 
dre råderum for de ældre og udøverne. Samtidig med at ældreområdets ydelser og administrative strukturer er blevet moderniseret, er de ældre og udøverne blevetumyndiggjort.

Kritikken har sat fokus på en paradoksal effekt af ældreområdets forberedelser til marked, nemlig at det arbejde, der har haft til formål at skabe synlighed i ældreområdets strukturer, samtidig har gjort sider af omsorgsudøvelsen sværere at få øje på. Synligheden er blevet hævet uden for omsorgsrelationen, hvor politikere, administrative medarbejdere, potentielle leverandører og kommende hjælpemodtagere har kunnet iagttage ældreydelserne i et nyt lys, mens sigtbarheden i selve omsorgsrelationen er faldet tilsvarende.

Og hvordan med de ældre, er deres indflydelse blevet påvirket af markedsforberedelserne? Ja, som den ovenstående kritik tydeliggør, er mulighederne for at involvere de ældre i plejen mindsket. Man kan tale om en ny personkonstruktion, den umyndiggjorte ældre. En personkonstruktion som mildest talt ikke er særlig markedsegnet. Hvilken interesse har denne person i marked? Med behov fastlagt af områdets eksperter og sat uden for indflydelse kan man ikke en gang være sikker på, at personen besidder en evne til at træffe egne valg.

\section{EIdrepakkens principper}

Da den borgerlige regering kommer til magten i slutningen af 2001, står man med et åbenlyst problem. Alt er klargjort til marked, kommunerne har indført kvalitetsstandarder og fæelles sprog, man har organiseret sig i kontraktstrukturer og fra Socialministeriets side er afsat ressourcer til et gennemgribende moderniseringsarbejde, men samtidig spøger konstruktionen af en passiv ældreaktør i kulissen. Denne personkonstruktion er man endt op med som følge af det omfattende kvalitets- og standardiseringsarbejde. Det er en personkonstruktion, som er alt andet end markedsegnet. Situationen er ikke heldig. Billedet af den klientgjorte ældre tydeliggør et afgørende paradoks i markedsdannelsen. Det er svært at finde argumenter for, at denne ældre skulle ønske flere valg end det ene offentlige, hun allerede har. Er marked kun muligt, hvis den ældre samtidig konstrueres som umulig aktør på dette marked? De initiativer, man har sat i gang for at understøtte strukturudviklingen i markedsretning, har samtidig konstrueret en ældrerolle, som ikke fungerer på et marked. Regeringen står i den vanskelige situation på den ene side at have beslutningsstrukturer, som er klargjort til marked, på den anden side at have en ældrerolle, som passer bedre til et traditionelt velfærdssystem uden markedsvalg og konkurrence. Før man stiller sig et marked for ældreydelser i udsigt, må man spørge sig, om det er muligt at ændre denne rolletilskrivning: Er det muligt at genopfinde den ældre som autonom og selvbestaltet individ?

For regeringen er situationen alt andet end enkel, og situationen bliver ikke lettere af, at man i valgkampen har taget kraftig afstand fra det, man kalder socialdemokratisk systemtankegang, og det selvom man godt ved, at en afgørende betingelse for markedsdannelse i den offentlige sektor er flere standarder 
og større synlighed. Marked kræver tællelighed og systematik - det hvad enten regeringen er socialdemokratisk eller venstre. For regeringen handler det kort og godt om administrativ opgradering i kommunerne, og samtidig handler det om, som en anden Dr. Frankenstein, at give liv til en ny og vitaliseret ældrefigur.

I regeringen lægger man en offensiv strategi og formulerer ældrepakken som en samlet programerklæring for de to forehavender: Dels at videreføre markedsog kvalitetsarbejdet fra det foregående årti, dels at installere en ny brugerkonstruktion, den frit vælgende ældre.

Ser man nærmere på ældrepakken, markerer pakken et fundamentalt skift i tilgangen til marked. Særligt formen er ny. Det er første gang, at en regering søsætter en markedsreform for et samlet velfærdsområde. Regeringen kombinerer kvalitetsstandarder med kontraktstyring og frit valg. Denne kombination er ikke set tidligere. Det er en reguleringsform, der byder på både mere politik og administration samt mere markedskonkurrence. Desuden er det en reguleringsform, der byder borgerne et hidtil uset ansvar. Hvor det i tidligere udliciteringstiltag var kommunerne, der bestemte andelen af privat opgaveudførsel, er det nu de ældre, og med dem er et selvvalgsrationale bragt på banen.

Ved siden af selvvalgsrationalet udgør tre principper hjørnestene i ældrepakken. Det handler om a) at installere et nyt politisk reguleringsprincip, om b) at ændre principperne for de organisatoriske strukturer, om c) at indsætte nye principper for identificeringen af de ældre samt $d$ ) om at etablere selvvalg som et styrende princip for ældreområdets markedskonkurrence.

Figur 2: Ældrepakkens principper

\begin{tabular}{|c|c|}
\hline Et reguleringsprincip & Et struktureringsprincip \\
\hline a) Kvalitets- og godekendelsesmodel & b) Bestiller og udførerorganisering \\
\hline Et identifikationsprincip & Et markedsprincip \\
\hline c) Retssikkerhed og visitation & d) Frit valg \\
\hline
\end{tabular}

De fire principper markerer et sporskifte i ældreservicen. Selvom fagligt kyndige medarbejdere stadigvæk skal beslutte, hvilke ydelser de ældre kan modtage, endog hvilke behov de har, og selvom politikere stadigvæk udstikker kommunernes service- og kvalitetsniveau, så er de ældre tilskrevet en afgørende rolle i beslutningstagningen. Det er den enkelte ældre, der skal træffe beslutningen om offentlig eller privat hjælp. Det politisk-administrative systems myndighedsrolle og de private firmaers udbudsret er afbalanceret af en ny valgfrihedslogik. 
Den ældre kan som noget nyt nu selv vælge, hvem der skal udføre hjemmehjælpen, og de skal inddrages aktivt i tilrettelæggelsen af hvilke gøremål, der skal udføres hvornår (Socialministeriet 2002).

Kigger man på ældrepakkens hoveddele, er der tydelig reference til ældremarkedets vigtigste aktører, nemlig de kommunale myndigheder, forbrugerne og leverandørerne.

\section{1) Frit valg af leverandør}

Den første del handler om frit valg af leverandør. I orienteringen til loven specificeres det, at de ældre skal have mulighed for at vælge mellem flere leverandører, og at kommunerne derfor forpligtes til at give adgang til private aktører, der dog må leve op til kvalitetskrav fastsat af kommunen (L 130; Orientering om L 130).

\section{2) Kvalitetsstandard}

Den anden del i lovpakken tager udgangspunkt i et allerede eksisterende lovkrav til kommunerne om at formulere kvalitetsstandarder. Af "lov om kvalitetsstandard" fremgår, at standarderne har til formål at sikre sammenhængen mellem politikernes overordnede prioriteringer og ældreområdets konkrete ydelsesniveau samt at sikre et fælles kvalitetsniveau for konkurrencen (L 130; Orientering om L 130; LBK 755: §§ 74a; 75c; Vejledning af 9. oktober: §§ 1, 2; 7-17). I loven specificeres to programmer for kommunernes myndighedsudøvelse: en såkaldt "godkendelsesmodel" og en alternativ "udbudsmodel" (LBK $755 \S 75$ c stk. 2).

\section{3) Retssikkerhed}

Det tredje princip i ældrepakken vedrører spørgsmålet om retssikkerhed. Regeringen fremhæver kommunalbestyrelsens myndighedsansvar og specificerer dens rolle som fastlægger af kommunens serviceniveau. I orienteringen lægges vægt på, at serviceniveauet sikres både konkret og alment. På det generelle plan pålægges kommunerne at sikre sig retningslinjer for udvælgelsen af firmaer, på det konkrete plan at sikre sine hjælpeafgørelser (L 130; Orientering om L 130:5).

\section{4) Fleksibilitet}

Den fjerde og sidste del vedrører spørgsmålet om fleksibilitet. En eksisterende "lov om fleksibel hjemmehjælp" reformuleres. Denne lov lægger principperne for den daglige hjælpesituation fast. Loven er pragmatisk udformet og ændrer ikke på hjælpesituationens grundlæggende strukturer. Den enkelte ældre har mulighed for i særlige tilfælde at fravige det i forvejen besluttede, altså bytte eller erstatte tildelte ydelser med andre ydelser, men det er stadigvæk i visitationen, at hjælpen lægges fast (L 130; Orientering om L 130:5).

Lovændringerne medfører flere ændringer i ældreområdets strukturer, som det vigtigste ændres rollesammensætningen på området. Med pakken bliver de 
ældre til frit vælgende forbrugere af serviceydelser. De private firmaer bliver leverandører af politisk regulerede servicepakker. Og kommunerne bliver til markedsregulatorer. To principper knytter de nyudnævnte markedsaktører til hinanden, "frit valg" og "kvalitetsregulering". Med disse principper har kommunerne, på den ene side, mulighed for at udmønte deres politiske myndighedsrolle gennem at stille kvalitetskrav, mens de ældre og leverandørerne, på den anden side, har mulighed for at udmønte deres markedsrolle gennem henholdsvis at efterspørge og udbyde service.

Figur 3: Ældremarkedets aktører

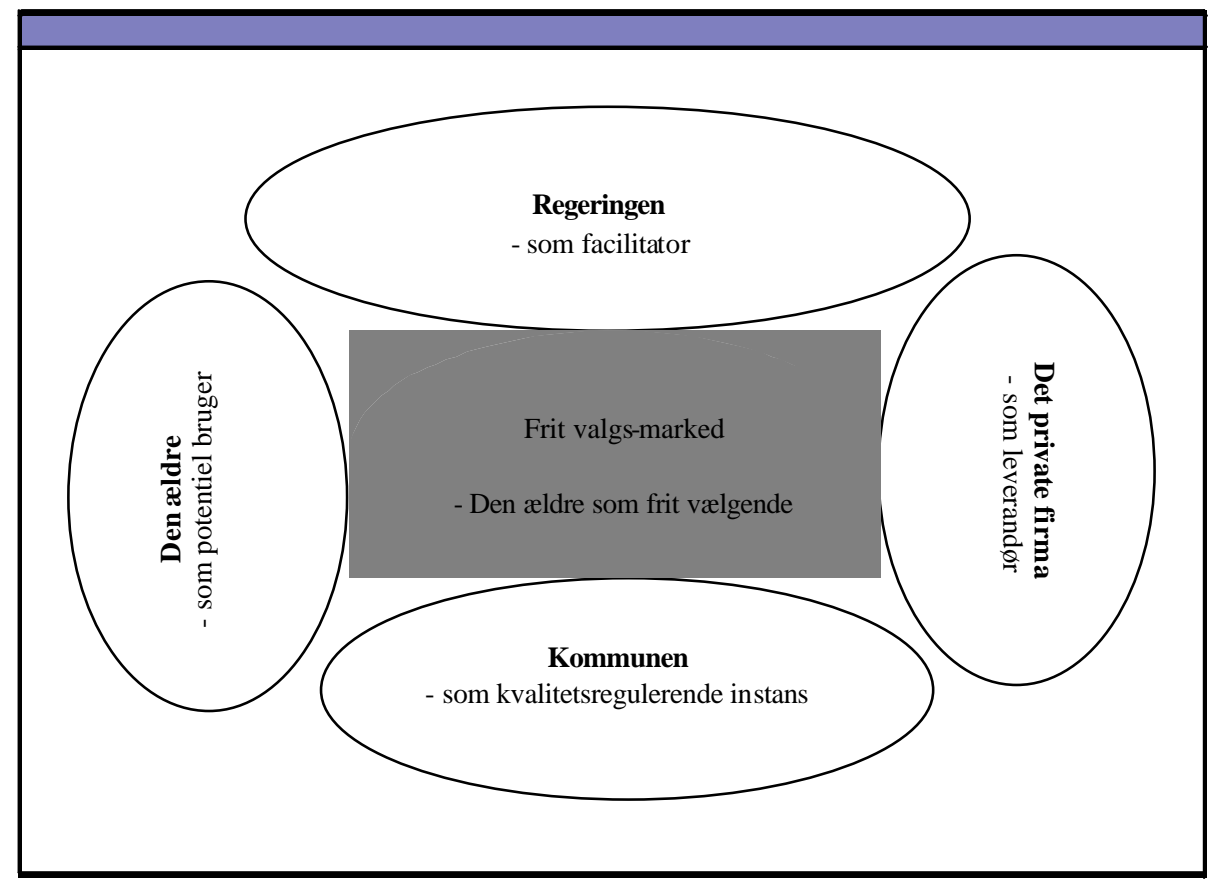

\section{Den frit vælgende ældre i centrum}

Som det er fremgået af den hidtidige analyse, erfrit valg et helt afgørende princip i ældrepakkens markedsdannelse. Med dette princip er en ny beslutningslogik sat i spil på ældreområdet, og en ny aktørkonstruktion sat i centrum af beslutningstagningen. Den frit vælgende forbruger er kommet på banen og afgør, om hjælpen tilvejebringes i offentligt eller privat regi. Det handler om tilskrivning af identitet. En ny rolle er konstrueret, som de ældre forventes at tage på sig.

Princippet om frit valg og den dertilhørende beslutningstagerrolle som frit vælgende er ikke en enestående konstruktion i markedsdannelsen. Selvom regeringen har gjort frit valg til afgørende princip, betyder det langtfra, at samtlige 
andre beslutningsprincipper er væk. Billedet er snarere, at flere sideordnede principper er bibeholdte - og med mange principper er der beslutningstagerroller til alle. Politikere forventes at tage beslutninger om kvalitet. Eksperter forventes at definere behov og ydelser. Leverandørfirmaer beslutter udbud. Medarbejdere træffer enkeltbeslutninger om hjælp og så fremdeles. Spørgsmålet er, hvilke betingelser der er for koblingerne mellem disse beslutningstagerroller.

I besvarelsen af dette spørgsmål giver det god mening at tage udgangspunkt $i$, at den frit vælgende ældre står i centrum. Man må dog forstå begrebet centrum radikalt anderledes end i dagligdags sprogbrug. Det handler om tilskrivning. Centrum er ikke et rumligt eller geografisk begreb. Heller ikke skal det forstås i ental. Centrum er et "mange-sted". Ældreområdets mange beslutningstagere får med ældrepakken et fælles program at orientere sig efter. Ud fra dette program reproducerer de hver især forestillinger om ældremarkedets centrum. Der er et centrum for hver aktør, og den frit vælgende ældre står i centrum på markedet, i den forstand at markedets andre aktører orienterer deres iagttagelser i forhold til denne rollekategori. Det betyder, at de ældres centrale status er tilskrevet og operationel. Det handler om, at de andre aktører former og opretholder en forestilling om den frit vælgende ældre som central beslutningstager. Man kan også sige, at hver enkelt aktør tegner sit eget billede af den frit vælgende xldre. Det betyder, at der er lige så mange billeder som aktører. Den frit vælgende xldres centralitet er formet af forskellige beskrivelser, men samtidig af forestillingen om et fælles centrum. Ældreområdets aktører, der har vidt forskellige motiver for at beslutte og handle, får med forestillingen om frit vælgende forbrugere mulighed for at afpasse deres operationer efter hinanden. Private firmaer vil afpasse deres udbud med kommunernes kvalitetsstandarder, og kommunerne vil tænke i fremtidige serviceniveauer og ydelseskategoriseringer med reference til de frit vælgende ældre. Hvis ikke for dem, hvem så?

Der er tale om en subtil enheds- og differentieringslogik, hvor mange systemers differentieringer afpasses som følge af en fælles referenceramme. Forskellige organisationssystemer omkranser markedet, men installeres med en fælles forestilling om den frit vælgende ældre. Ved at referere til de ældre er det muligt for beslutningstagerne at koble væsensforskellige beslutninger sammen. Kommunens politikere beslutter kvalitetskrav med blik på de ældre, de private leverandører træffer økonomiske dispositioner med blik på de ældre, og så fremdeles. Et marked kræver mange beslutninger og beslutningssammenkoblinger, og enheden risikerer at forsvinde. Det er derfor vigtigt, at alle har en overordnet forestilling at henvise til. I systemteoretisk terminologi kan man tale om en fælles kontingensformel (Krause1996) eller trylleformular (Moe 1998). En sådan trylleformular får beslutningstagerne på ældreområdet med det frie valg. Fordi “det frie valg" repræsenterer en egen rationalitet, fordi valget er personligt og frit, peger det ud over systemernes beslutningslogikker. Det frie valg peger i retning af en enhed, alle kan tilslutte sig. Og samtidig peger det i retning af en åbenhed. Valget repræsenterer så at sige en selvstændig rationalitet, som de andre beslut- 
ningstagere må forholde sig til. Beslutningstagerne kan ikke uden videre antage, at deres egen rationalitet er den eneste rigtige, men må forholde sig til de ældres mange individuelle dispositioner. De ældres frie valg symboliserer, at ingen beslutning har forrang - at det i sidste ende er de ældre, der beslutter selv.

Valget står i centrum, men fungerer samtidig som en yderside til ældreområdets andre beslutninger. Når ældremarkedets andre aktører træffer beslutninger, dannes beslutningskredsløb, hvori refereres til frit valgs-beslutningen. I disse kredsløb refereres til det frie valg som et udenfor. Og netop dette er vigtigt. Det, at der er et frit valg, gør differentiering mulig. Beslutningstagningen differentieres sideordnet, modsat over/underordnet. Både politiske, økonomiske, juridiske og hjælpefaglige beslutninger har betydning for de ældres frie valg. Ingen rationalitet, intet kredsløb har forrang.

\section{Den frit vælgende ældre som grænsedrager}

Man kan spørge, hvor grænsen går mellem offentlig og privat. Svaret er ikke entydigt. På et blandingsmarked som det på ældreområdet agerer både offentlige og private beslutningstagere. Mange aktører træffer beslutninger, men uden at en enkelt beslutning har forrang: En politisk beslutning om kvalitet er lige så vigtig som en økonomisk om effektivitet. Beslutningerne er sideordnede og lige nødvendige for blandingsmarkedets funktionsevne. Beslutningerne er afgrænsede, men hænger sammen. Således gælder, at når én beslutningstager træffer en beslutning, lader han sig orientere af beslutninger truffet af andre beslutningstagere. Grænserne er opretholdte, men udfordrede. Det er ikke selvfølgeligt, hvorfor grænserne er trukket, som de er. Der er risiko for grænsestridigheder og konflikter. På frit-valgs-markeder harden frit vælgende ældre rollen at trække grænser.

Kigger man nærmere på denne rolle som grænsedrager, er den baseret på en ganske særlig type tilskrevet autoritet. Man kan også sige, at den ældre kun fungerer som grænsedrager, fordi han har fået tilskrevet hvervet at vælge mellem offentlig og privat hjælp. Med dette valg markerer han en af blandingsmarkedets grænser.

Andre grænser og andre grænsedragere er også på spil: En kommunalbestyrelse formulerer et serviceniveau og trækker herved en grænse mellem legitime ældrebehov og ikke-behov. En leverandør beslutter sin deltagelse og er herigennem med til at definere et forhold mellem den offentlige og private andel af leverandørkorpset. En medarbejder beslutter om hjælpens udførelse og trækker hermed en grænse mellem de administrativt definerede ydelser og den situationelt betingede indsats. Alle aktørerne trækker grænser. Grænserne er forskellige og har forskellig betydning for beslutningstagningen, men er trukket med den samme reference til den ældre: Kommunen iagttager den ældre som borger med bestemte forventninger og krav, firmaerne iagttager hendes efterspørgsel efter ydelser, og medarbejderne iagttager, hvilke behov hun har for hjælp.

I hvert fald tre grænsedragningslogikker er på spil samtidig. For det første en 
selvbestemmelseslogik. For det andet en ekspertlogik, og for det tredje en situationel logik.

Således gælder, at når de ældre vælger leverandør, er de autonome og selvbestaltede, her råder selvbestemmelsen, mens de, når visitatoren træffer beslutninger om deres behov og tildeler dem ydelser, er afhængige af andres vurderingsevne og dømmekraft, altså indgår i en ekspertstyret beslutningskontekst. Når de står i omsorgssituationen råder en situationel logik, hvor de forventes at lade dialogen råde.

Også her er det vigtigt at slå fast, at det handler om rolletilskrivning. De ældre indgår i forskellige beslutningssituationer og tilskrives i disse situationer forskellige roller afpasset situationerne. I den nedenstående figur er beslutningssituationerne indtegnet. Først ses situationerne, dernæst rolletilskrivningen. I den tredje og fjerde linje ses henholdsvis den grænsedragningslogik og forskel, der virker definerende for situationen.

Figur 4: Tre beslutningssituationer

\begin{tabular}{|c|c|c|}
\hline Frit valg-situation \\
Den frit vælgende ældre \\
Offentlig lprivat
\end{tabular}$\sqrt[\begin{array}{c}\text { Omsorgssituation } \\
\text { Den behøvende ældre } \\
\text { Ekspertlogik } \\
\text { Behov lydelser }\end{array}]{\begin{array}{c}\text { Situationel logik } \\
\text { Hjælp } \mid \text { selvhjælp }\end{array}}$

Figuren peger i retning af brydninger mellem rolletilskrivningerne i de tre situationer. På den ene side forventes politikere og eksperter at sætte markedets kvalitative standarder og dømme behov eller ej. På den anden side forventes udøvere at træffe beslutninger afpasset den situation, de står i, mens det af de ældre er forventet, at de træffer valg baseret på personlige præferencer. Tre grænsedragningslogikker støder sammen. Hvem trækker områdets grænser? I alle tre tilfælde er der tale om, at der trækkes grænser for de ældres inklusion. Inklusion handler om, hvor på ældreområdet de ældre optages og på hvilke præmisser. Men inklusion handler også om, hvordan de ældre delagtiggøres i beslutningerne om egen livssituation. Her ses det, at de ældre, delagtiggøres forskelligt alt afhængig af kontekst. Således gælder, at når de ældre vælger offentlig eller privat hjælp, beslutter de selv deres inklusion. Anderledes ser det ud, når visitator fastlægger de ældres behov og tildeler dem ydelser. Her er tale om en ekspertstyret inklusion. I omsorgssituationen, hvor hjemmehjælperne interagerer med de ældre, er der tale om en situationsbetinget inklusion. De tre inklusionsformer er væsensforskellige, hvilket peger i retning af potentielle konflikter. Situationen for det frie valg udtrykker, at de ældre selv trækker grænserne for deres indopta- 
gelse i ældreplejen, mens visitationen markerer det modsatte, at de ældre må indordne sig grænser trukket af andre. Omsorgssituationen repræsenterer en både/og-form, hvor grænser er til forhandling.

Det er i denne sammenhæng vigtigt at se, at ældrepakken installerer en plural inklusionslogik. Flere beslutningskontekster har betydning for inklusionen, og i hver kontekst fungerer en egen logik. Således inkluderes de ældre i én kontekst ud fra en markedsmæssig logik, mens de i andre kontekster inkluderes på henholdsvis velfærdspolitiske-, hjælpefaglige-, juridiske- og bureaukratiske præmisser. Grænserne trækkes forskelligt, og de ældre er ikke feltets eneste grænsedragere. Kommunalbestyrelser og kommunale administratorer foretager velfærdspolitiske og bureaukratiske afgrænsninger, visitatorer foretager hjælpefaglige afgrænsninger, og medarbejdere afgrænser udførslen. Disse aktører er alle grænsedragere, og hvor det er kendetegnende, at de træffer beslutninger om inklusion på præmisserne af det respektive beslutningssystem, de står i, er det kendetegnende, at de ældre giver ældreområdets beslutningstagning et menneskeligt ansigt. Når brugere vælger selv, betyder det, at inklusion ikke kun handler om systempræmisser, men også om personers råderet. Et frit valg signalerer, at grænsedragning handler om menneskers autoritet over egen livssituation.

\section{Rollepluralisme som betingelse for inklusion}

Vi har lige set, at visitationen, situationen for det frie valg og omsorgssituationen er formet om vidt forskellige forventningsstrukturer: I visitationen er det eksperter, som trækker grænser. Det sker, når de definerer behov. Her er det specialister, der hersker, og kvalitetsstandarden er deres beslutningsteknologi. I situationen for det frie valg virker en anden beslutningslogik, her trækker de ældre grænserne selv. De er mægtiggjorte og har autoritet og ret til at definere egen livssituation. I omsorgssituationen er det hjælpeudøveren, der i dialog med den hjælpemodtagende ældre udøver et fagligt skøn betinget af situationen.

Tager vi udgangspunkt i denne tredelte struktur, fremstår det klart, at betingelserne for rolledannelse er plurale. I hver situation er formet egne sprog- og forventningsstrukturer. De ældre må tage flere roller på sig, når de træder i karakter for ældreområdet.

Anderledes formuleret kan man også sige, at den tredelte struktur er udtryk for en velfærdsorganisering, hvor man har differentierede inklusionspræmisser med tilhørende rolledifferentieringer. Forskellige personer er tildelt beslutningsautoritet over inklusionen. Den operative logik er, at et rollegalleri er skabt i ældreområdets kommunikation. Rollerne i dette galleri har kun afgrænsede koblingslinjer til de psykiske og fysiske processer i omverdenen. Man kan med et begreb fra Teubner/Hutter (2003) sige, at rollerne er virkelige fiktioner. De er kommunikeret frem og er i denne forstand opfundne. Samtidig har de betydning for hjælpens beslutning og udførsel. Rollernes udseende definerer, hvilke sider af de ældres liv som har relevans. Man kan også sige, at rollerne former ældreområdets irritabilitet eller sensibilitet i forhold til de ældre. 
Lad mig uddybe. I ældreområdets rollegalleri ses i hvert fald fire beslutningstagerroller. De fire roller er klargjort til, at de rette personer kan komme og iføre sig dem. Fire personer er potentielt set tilkendt beslutningsautoritet, når de træder ind på området og iklæder sig rollerne. For det første har vi en visitatorrolle. Visitator beslutter behov og ydelser. Over for hende sidder en ældre uden beslutningsautoritet, kun tilkendt en ret til at ytre sig om egne behov. For det andet har vi rollen som frit vælgende ældre. Denne rolle indbefatter, at man er tilkendt ret til selv at vælge placering i offentligt eller privat regi. Over for den frit vælgende xldre sidder en medarbejder og tager mod bestilling. For det tredje har vi en omsorgsgiverrolle og for det fjerde en omsorgstagerrolle. Iklædt de to sidste roller forventes personer at stille sig $i$ et situationelt betinget spil om delt beslutningsautoritet.

Det gælder for alle fire roller, at de er konstruktioner skabt $\mathrm{i}$ ældreområdets kommunikation. De får først liv, når personer gør dem til deres og giver dem indhold. Når det sker, transformeres de til virkelige anknytningspunkter for beslutningstagningen. Rollerne transformeres og bliver til levende beslutningstagere med relativt forskelligt udseende. De personer, der tager rollerne på sig, forventes at agere forskelligt. Visitator er ekspert, den frit vælgende ældre er privatperson, omsorgsgiveren er fagperson og omsorgsmodtageren er behovsbærer. Vi har fire beslutningstagere, der forventes at træffer deres beslutninger forskelligt: Visitator forventes at beslutte ud fra faglige kriterier og standardteknologi, den frit vælgende ældre forventes at beslutte uden at give gode grunde for sine valg. Omsorgsgiveren og omsorgstageren forventes at beslutte i situationen og med henvisning til, hvad der her har vist sig mest rigtigt at gøre. Ét sted med sikkerhed for en lige vægtning af politiske, økonomiske og omsorgsfaglige hensyn. Et andet sted med autoriteten overladt til privatpersoner og med vægtning af disses egeninteresse og behov, et sted, hvor de ældre ved bedst og på egne præmisser beslutter, hvorfra de ønsker hjælp. Et tredje og sidste sted med sikkerhed for både fagligt forsvarlige og individuelt tilpassede løsninger, en omsorgssituation på både den ældres og systemets præmisser.

Man kan også sige, at der i de tre situationer - henholdsvis visitationen, situationen for det frie valg og omsorgssituationen - formes forskellige meningshorisonter om ældrehjælpens beslutningstagning.

I situationen for det frie valg er beslutningstagningen socialt orienteret, her personificerer de ældre, at man som bruger har ret til at sætte grænser på egne vegne. De ældre giver beslutningstagningen ansigt og navn og sikrer herigennem markedsdannelsen social mening. Beslutningen om offentlig eller privat hjemmehjælp er ikke en beslutning taget af en ekspert, men er de ældres egen. Beslutningen forventes ikke bakket op af saglige argumenter for eller imod. Beslutningen er rigtig per definition, ene og alene med reference til beslutningstagers status som privatperson med egne præferencer, ønsker og mål. I rollen som frit vælgende er de ældre fritaget fra at give gode grunde for deres valg.

I visitationen derimod sættes en helt anden horisont. Her produceres et væld 
af gode grunde. Om de ældre skal have ydelsespakke 4 eller 5, besluttes med sagsorienterede argumenter. Det handler om den ældres behov og områdets ydelser. Eksperter beslutter hjælpen og dens indhold og sætter herigennem et sagsforhold i centrum.

I omsorgssituationen er meningsdannelsen blandet. Her er både sociale og sagsmæssige argumenter på spil. Også kan der være tale om en vigtig tidsmæssig dimension, dette hvis hjælpen tilvejebringes i en struktur kendetegnet af ekstremt ekspliciteret kronologi, som det f.eks. ses i en hjemmehjælp, hvor teknologier som tidsstandarder, palm pilots og stregkoderegistrering er blevet hverdag (Szebehely 2005).

Man kan konkluderende spørge, hvilket forventninger der rettes mod de ældre i henholdsvis visitationen, situationen for det frie valg og omsorgssituationen. Svaret er, at rollen, de tilbydes i visitationen, gør dem til sager til afgørelse, mens de i situationerne for de frie valg forventes at være sagernes afgørere og i omsorgssituationen forventes at være både/og. Inklusionen er multipel, i den forstand at deældre må lev op til flere roller, for at blive gjort til genstand for velfærdsstatslig kommunikation. Når de ældre træder ind i visitationen, forventes de åbne for udfyldning, når de træder ud igen er det med veldefinerede behov. I situationen for det frie valg forventes de snarere at være beslutningstagningens ankerpersoner. Her træder de ind med en forhåndsdefineret evne til at træffe frie valg og træder ud som fuldbyrdede beslutningstagere. I omsorgssituationen forventes de at deltage i beslutningstagningen og er samtidig konstrueret som objekter, der træffes beslutninger om.

Det handler om inklusion på præmisserne af multipel rolletilskrivning. De ældre tilskrives forskellig rolle afhængig af situationen, de indgår i. Eller kan man også sige: De ældre farves af den beslutningskontekst, de træder ind i.

\section{Paradokser i hverdagen ${ }^{7}$}

At multipel inklusion er en udfordring ses i hverdagen, hvor de ældre møder modsatrettede forventninger. De ældre har på dette tidspunkt været $i$ to beslutningssituationer. I visitationen har de været til vurdering, og i frit valgssituationen har de truffet et valg mellem offentlig og privat hjælpeudøvelse.

I hverdagen er forventningsdannelsen farvet af de tidligere situationer. De ældres hverdagsrolle matcher både den tidligere behovsbærer-og frit valgsstatus. I hverdagen forventes de ældre både at være ikke-beslutningstagere og beslutningstagere. De forventes på samme tid at være objekter og subjekter for beslutninger. Én side af hverdagsrollen er fastlagt af velfærdsfaglige eksperter. Denne side består af behov, som modsvares af ydelser. Denne side ligger uden for de ældres beslutningsrækkevidde. En anden side refererer til det frie valg, denne side repræsenterer det selvvalgte. I hverdagen støder to rationaliteter sammen: En frit valgs- og en vurderingsrationalitet. Retten til selvbestemmelse står over for en pligt til at lade sig beslutte om.

Hvad kan siges om hverdagen som en særlig kontekst for beslutninger? At 
det er her de handlingsorienterede beslutninger ligger placeret. Det er i hverda-

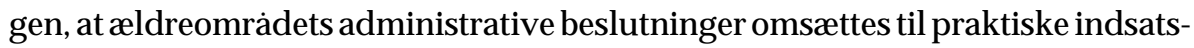
punkter. I strukturelt henseende er dette formål styrende: at koble administrativt orienterede beslutninger sammen med praktiske. Selve koblingen er afgørende og peger i retning af, hvilken handlingsorientering beslutningstagningen har. I forvejen er truffet administrative beslutninger. De ældre har fået fastlagt deres behov og er blevet tildelt et afgrænset antal ydelser. De administrative forhåndsbeslutninger skal knyttes sammen med de i princippet uendelige udfordringer, man står over for i den faktiske hjælpesituation. Det er afgørende, at beslutninger og udfordringer kobles rigtigt sammen. Er et problem af en sådan karakter, at

Figur 5. En kobling mellem to beslutningstyper

\begin{tabular}{|l|l|}
\hline $\begin{array}{l}\text { Administrative beslutninger } \\
\text { truffet på forhånd }\end{array}$ & $\begin{array}{l}\text { Beslutninger om } \\
\text { udfordringer i situationen }\end{array}$ \\
Handlingsorienterede beslutninger
\end{tabular}

det kræver konkret stillingtagen, eller kan man henholde sig til de administrative forhåndsbeslutninger? Afgørelsen er vigtig, men ligger på en måde uden for de ældre og medarbejdernes rækkevidde. Det handler om, hvor stregen trækkes og ikke om hjælpens indhold. Her er det hverken nok at administrere med beslutninger truffet på forhånd eller i situationen. Man må overskue begge sider af beslutningstagningen, stille sig udenfor og trække stegen fra et tredje-sted. Det handler om at udøve refleksiv kunnen, hvilket indbefatter at tage stilling til hele forskellen med begge dens sider. Hvor står de ældre og medarbejderne, når de udøver denne refleksivitet? Fagpersonen står over for brugeren, hvem ved bedst? Den ældre kender sine behov, fagpersonen kender det administrative råderum, men hvem kender den rette dosis administration og situation?

I ældrepakken gives ikke et entydigt svar på spørgsmålet. I lov om fleksibel hjemmehjælp ligger en antagelse om, at de ældre og hjemmehjælperne i fællesskab beslutter, om de administrativt besluttede forhåndspræmisser skal fraviges eller opretholdes. Man kan også sige, at lov om fleksibel hjemmehjælp gør det muligt at forskyde det uafgørbare spørgsmål om, hvilke principper der skal veje tungest de administrative eller de hverdagslige. Loven virker så at sige som en tranformationsmekanisme, der gør det muligt at træffe handlingsorienterede beslutninger på trods af hverdagens grundlæggende uafgørbarhed og admini- 
strationens ufuldkommenhed. Der er skabt en beslutningsåbenhed i et ellers lukket beslutningsrum. Loven giver de ældre og medarbejderne ret til fra tid til anden at tilsidesætte beslutninger truffet $i$ den forudgående visitation. Men samtidig med at loven har skabt forventninger om, at de ældre og medarbejderne er i stand til at trække den vanskelige grænse mellem de administrativt orienterede og de praktisk orienterede beslutninger, så er der skabt en uafgørbarhed omkring de ældre og medarbejdernes roller. Deres roller er lagt fast, men med princippet om fleksibilitet forventes de at spille forskelligt ind med deres personlighed. Muligheden for personlig udfyldning af rollerne skifter, alt afhængig af om de gør brug af retten til fleksibilitet eller ej.

\section{Den frit vælgende ældre som betingelse for marked}

Det er tid at trække artiklens vigtigste pointer frem.

En første pointe angår differentiering. Ældrepakken tegner konturerne af et velfærdsmarked, hvor flere principper råder samtidig. I forskellige systemer tages beslutninger om hjælpen, og ældrepakken har til formål at sikre disse beslutningers sammenhæng. Sammenhæng skal her forstås som det, at beslutningstagerne i ét system lader sig orientere af beslutninger truffet $i$ andre systemer.

Det er vigtigt at holde fast $i$ det forhold, at ældrepakken skaber sammenhæng på betingelserne af differentiering. Markedsbaserede beslutningslogikker føres sammen med faglige og administrative logikker via politisk koordinering. Den politiske koordinering er dobbelt betinget. På den ene side er den betinget af regeringen, der har ansvar for markedets samlede funktionsduelighed, på den anden side af enkeltkommuner med ansvar for markedets kvalitetspræmisser. Denne dobbeltsidede politiske regulering sætter rammerne for de beslutninger, der føres sammen. Dette ses, når en given ældre beslutter, hvor fra han eller hun ønsker at modtage hjælp. Her udløses en efterspørgselslogik, der er politisk styret. Og det ses, når en privat eller offentlig leverandør beslutter, hvilke ydelser der ønskes udbudt. Her frisættes en politisk reguleret markedslogik. Nærmere bestemt frisættes en udbudslogik på kvalitetsregulerede præmisser.

Differentiering handler om, at ældrepakken åbner for et spændingsforhold mellem et politisk funderet reguleringsprincip, et markedsbaseret selvreguleringsprincip og et fagligt baseret ekspertprincip. På den ene side er en gruppe borgere tilkendt ret til selv at vælge leverandør, på den anden side er skabt betingelser for en udvidet politisk og faglig regulering i form at kvalitetsstandarder og serviceniveaubestemmelser.

En anden pointe vedrører rolletilskrivning. Artiklens analyser har vist, at frihed ikke er det eneste, der følger af at få tilkendt frit valg. Således gælder, at når de ældre tager frit valgs-rollen på sig, så gør de sig samtidig åbne for ansvarstilskrivninger og forventninger. Det gælder, at når de tager mod invitationen om at blive frit vælgende, så forpligter de sig samtidig til et bestemt selvforhold. Rammerne for dette selvforhold er formuleret udefra. Rammerne er sat af regeringen og 
forankret i administrativ kvalitetsstyring. Paradokset er uomgængeligt. De ældre forventes at tage en frit valgsidentitet på sig inden for politiske rammer, der ikke er til diskussion.

Anderledes formuleret handler frit valg om en rolletilskrivning, som har noget fuldstændigt over sig uden at være det. At være frit vælgende lugter af fuldstændig autoritet. Analyserne har vist, at der sammen med rollen som frit vælgende følger andre rolletilskrivninger. De to vigtigste tilskrivninger er de som henholdsvis behovsbærer og ydelsesmodtager. Det afgørende er i denne sammenhæng, at de tre roller er forskellige, men bundet sammen. Endvidere er det afgørende, at kun den ene rolle en egentlig beslutningstagerrolle, mens de to andre roller handler om henholdsvis at blive besluttet om og om at modtage beslutninger. De ældre må med andre ord acceptere både at være besluttere og ikke-besluttere, uden selv at kunne beslutte, hvornår de er hvad. De er gjort til centrale beslutningstagere, men afgørende dele af deres beslutteridentitet er besluttet udefra. Med rollen som frit vælgende følger et krav om at tage mange roller på sig. Dette flersidige rollekrav er delvist skjult. Det er et krav om at indgå i en bestemt type selvforhold. De ældre er tilbudt en rolle som frie beslutningstagere, men med et krav om en flersidig udfyldning, der ikke er til beslutning.

En tredje pointe handler om inklusion. Hvem kan være imod frie valg? At blive tilkendt frit valg sender signaler om fuld indflydelse. Frit valg indikerer, at man selv bestemmer sin inklusion. I virkeligheden er billedet mere broget. Stadigvæk er der politisk og administrativt fastsatte præmisser for den velfærdsstatslige inklusion. Artiklen har vist dette for ældreområdet: På den ene side behovsvurderes de ældre. Deres identitet lægges fast og dermed deres indoptagelse, på den anden side er de tilkendt frit valg og har selv kontrol over deres inklusion.

Mere generelt handler det om, at velfærdsstaten gør sig afgørende afhængig af brugere med beslutningsautoritet, samtidig med at disse brugere er installeret med en afhængighed af velfærdsstatslig organisering. De er frit vælgende, men samtidig er deres behov lagt fast og de er tilkendt ydelser fra specialiserede systemer. Artiklen har søgt at afdække denne kobling mellem frihed og afhængighed. Det at blive tilkendt frit valg er ikke lig med betingelsesløs inklusion, sådan som det frie valg signalerer. Snarere installeres et netværk af præmisser og vilkår. Frit valg: Ja, men kun inden for politisk fastsatte rammer og underlagt fagligt tilsyn.

En fjerde pointe handler om ældrepakken som markedsprogram. Artiklen har tegnet et billede af den frit vælgende ældre som en brugerkonstruktion med særlige funktioner i markedsdannelsen. Som det vigtigste at være afvæbnende. Med frit valg er det de ældre, der træffer den afgørende beslutning om velfærdens placering, og fordi de træffer beslutningen uden at stå på offentlig eller privat side, opbløder de et potentielt set konfliktfyldt spørgsmål. Valget mellem offentlig og privat udøvelse er placeret hos en bruger, som ikke behøver give gode grunde for sine valg. Den frit vælgende ældreer skabt til at vælge og ikke til at begrunde. Han er en person, der indhyller snarere end åbner op. Tidligere lå 
markedsbeslutningerne som store, risikable beslutninger hos kommunalbestyrelserne. At beslutningerne ofte end te i konflikt, sås i forbindelse med udliciteringer (jf. Andersen 1997). Med introduktionen af frit valg er dette ændret. Beslutningen om privat eller offentlig velfærdsudøvelse ligger som et afgrænset valg hos en selvstændig brugerfigur. Denne brugerfigur kan markedets andre beslutningstagere skjule deres beslutninger bag.

Det særegne i ældrepakkens markedsmodus ligger i denne konstruktion: På den ene side er markedet afhængig af beslutningstagere, der forventes at redegøre for præmisserne bag deres beslutninger. På den anden side er markedet afhængigt af én beslutningstager, der ikke behøver give gode råd for sine valg.

Eller anderledes sagt: Markedet holdes oppe af ældre, der forventes at vælge leverandør uden at angive præmisserne for dette valg. Samtidig holdes en lang række beslutningssystemer oppe af beslutningstagere, der forventes at leve op til krav om åbenhed og gennemsigtige beslutningsstrukturer. Disse beslutningstagere kan tåle åbenheden, fordi de har et ydre (og mytisk) frit valg at referere til. Det frie valg udgør et fælles ydre legitimeringspunkt.

Man kan i denne sammenhæng tale om en politisk rationalitet, som med ældrepakken er gjort betinget af aktørers markedsadfærd. I ældrepakken er det de frit vælgende ældre, der giver ældreområdet viden om dets funktionsduelighed. Det er gennem de frie valg, at kommunerne får viden om de ældres tilfredshed. Offentlig eller privat service. De ældre betinger ældreområdets rationalitet, når rationalitet forstås som et områdes evne til at lade sig informere om sine indvirkninger på omgivelserne. ${ }^{8}$

I bredere forstand handler det om velfærdsstatens evne til at lade sig informere. Princippet om frit valg er introduceret på flere velfærdsområder, hvilket åbner for spørgsmålet om velfærdsstatens samlede informationshåndtering. Hvilke informationer bidrager de frie valg med på hvilke områder, og hvordan bidrager valgene til at retningsgive områdernes operationer? Selvom ideen om frit valg signalerer enhed, vil frie valg i praksis give forskellige informationer. Et frit valg truffet af patient giver anden information end eksempelvis et frit valg for et par børneforældre eller en socialklient. Frie valg signalerer enhed, at valget er det samme om borgeren står foran daginstitution, skole, sygehus eller plejehjem. I virkeligheden dannes væsensforskellige informationskanaler. Valgene giver informationer om afgrænsede sider af borgernes liv og identitet. Borgerne får råderet over nogle beslutninger, mens velfærdsområdernes eksperter beholder retten over andre. Borgerne optages som deltagere $\mathrm{i}$ forskellige beslutningssammenhænge. Som vist i forhold til de ældre, forbliver de i nogle sammenhænge at være traditionelle velfærdsmodtagere, mens de $i$ andre sammenhænge indoptages som nyslåede markedsaktører. Når borgere tager mod et tilbud om frit valg, så siger de samtidig ja til en flerhed af rolletilskrivninger.

Afslutningsvis kan det slås fast, at en umulighed er bundet til rollen som frit vælgende. Analyserne har vist det for de frit vælgende ældre. Det gælder generelt for alle brugergrupper med frit valg. Borgere, der har sagt ja til frit valg, har sagt 
ja til et tilbud, der ikke kan afslås, og har samtidigt åbnet sig for forventninger bundet sig til den rolle, de tager på sig. Rolletilskrivningen er ikke på valg. Den personlige udfyldning, derimod, er lagt åbent op. Borgerne inddrages i beslutningstagningen, men samtidig peger frit valg i retning af en særlig risiko for immunitet i det velfærdssystem, der tilbyder valgfriheden.

Et velfærdssystem udvikler immunitet, hvis de tror sig fuldt seende, men samtidig afgrænser sig. I værste fald skaber frit valg risiko for, at velfærdsstaten gør sig blind for interesser, der kommer til udtryk på andre måder end gennem frie valg. Sker det, vil markedsdannelsen forme velfærdsudviklingen snævert. De frie valg vil være gjort til fulde udtryk for borgernes interesser. Velfærdsstaten vil tro sig perfekt seende, men vil samtidig gøre sig systematisk blindt for andre informationer end de produceret af de frie valg. Man kan i denne sammenhæng tale om en form for hyperimmunitet.

Artiklens analyser har vist, atden frit vælgende ældre er en personkonstruktion blandt flere mulige. Hvis markedsdannelsen skal fremtidssikres mod immunisering, må strukturerne udvikles, så de understøtter flere sider af borgernes rolledannelse end frit valgssiden.

\section{Noter}

Tak for kommentarer til Niels Åkerstrøm Andersen, Anders la Cour, Chresten Højlund, Birgit Vibeke Lindberg, Steen Vallentin samt en anonym referee.

1. For nærmere udfoldelse af det systemteoretiske person/rollebegreb henvises til Luhmann (1995, 2000a: Kap. 8), Teubner/Hutter (2003).

2. I systemteoretisk optik har begrebsparret om inklusion/eksklusion særligt været behandlet hos Luhmann (2002), Nassehi/Nollmann (1997), Fuchs (1997), Gøbel/Schmidt (1998), Mortensen (2004: 141-147).

3. Der er efterhånden kommet flere antologier og tidsskrifttemanumre om systemteoretisk organisationsanalyse (Nordiske Organisationsstudier 2001; Højlund/Knudsen 2002; Bakken/ Hernes 2003; Seidl/Becker 2005; Organisation 2006). Luhmanns hovedværk om organisationer er Organisation und Entscheidung (2000b).

4. For uddybende diskussioner, se Højlund (2004:94).

5. Flere analyser har vist, at brugen af kvalitetsstander og "fælles sprog" ikke fører til besparelser i ansigt-til-ansigt-tid, dvs. i tidsforbruget hos brugerne (Schultz-Larsen 2004; A4 2004; Højlund 2005).

6. En opfølgning er iværksat i år, godt 5 år efter de første høringer. Socialministeriets treårige projekt "Kvalitet i ældreplejen" har til formål at åbne for forskellige tilgange til kvalitet (www.aeldreplejen.dk).

7. Hverdagen er en lidt misvisende betegnelse for den interaktion, hvor de ældre og medarbejderne omsætter politiske og administrative forhåndsbeslutninger til praktiske beslutninger om hjælpens udførsel.

8. For det systemteoretiske rationalitetsbegreb, se Luhmann (2000a:538). 


\section{Litteratur}

A4 2004: "Ministerium truer forskere med retssag",Ugebrevet A4 den 7. juni 2004.

Andersen, Niels Å. 1997: Udlicitering - Strategi og historie. København: Nyt fra Samfundsvidenskaberne.

Bakken, Tore/Tor Hernes (red.) 2002: Autopoietic Organisation Theory. Drawing on Niklas Luhmann's Social Systems Perspective. Oslo: Abstrakt forlag A/S.

la Cour, Anders/Holger Højlund 2001: “Den fleksible hjemmehjælper“, Social Kritik, nr. 76, 13. årg.: 6-19.

Finansministeriet 2000a: Benchmarking i den offentlige sektor. København: Finansministeriet, marts 2000 .

Fuchs, Peter 1997: “Weder Herd noch Heimstatt-Weder Fall noch Nichtfall. Doppelte Differenzierung im Mittelalter und in der Moderne", Soziale Systeme, 3. Jg., Heft 2: 413-437.

Greve, Carsten 2004: “Den stille revolution af velfærdssamfundet: Konkurrencestrategien og Strukturreformen". Notat for Ugebrevet A4.

Göbel, Markus/ohannes F. K. Schmidt 1998: “Inklusion/Exklusion: Karriere, Probleme und Differenzierungen eines systemteoretischen Begriffspaars", Soziale Systeme, 4 Jg., Heft 1: 87-117.

Hansen, Morten Balle/Evert Vedung 2005: Fælles sprog i ældreplejens organisering. Evaluering af et standardiseret kategorisystem. Odense:Syddansk Universitetsforlag.

Højlund, Chresten/Holger Højlund 2000: "Velfærdsparadoks og kommunikation. Fælles sprog en anden ordens strategi på hjemmehjælpsområdet", Grus, nr. 61, 21. årg.: 18-39.

Højlund, Holger Morten Knudsen (red.) 2002: Organiseret kommunikation. Systemteoretiske analyser. København: Forlaget Samfundslitteratur.

Højlund, Holger 2003: “Velfærdsforskydninger", pp. 267-296 in Christian Borch/Lars T. Larsen (red.): Luhmann og Foucault til diskussion. Perspektiv, magt og styring. København: Hans Reitzels Forlag.

Højlund, Holger 2004: Markedets politiske fornuft. Et studie af velfærdens organisering 19902003. København: Nyt fra Samfundsvidenskaberne.

Højlund, Holger 2005: “At give de ældre røst - tre brugerorienterede tilgange til udviklingen i ældresektoren", pp. 113-142 in Marta Szebehely: Äldreomsorgsforskning $i$ Norden. En kunskapsöversikt. København: Nordiska Ministerrådet, TemaNord 2005: 508.

Indenrigsministeriet 1994: Fornyelse og effektivisering i den kommunale sektor. Betænkning fra det af indenrigsministeren nedsatte udvalg om fornyelse og effektivisering i den kommunale sektor. Betænkning nr. 1268. København: Indenrigsministeriet, april 1994.

Institut for Serviceudvikling 2000: Certificering af Kvalitetsledelse og -udvikling i Æ ldresektoren. Erfaringer. http:/wwww.kvalitetsledelse.dk/Kommunernes Landsforening (1998a): Fælles sprog på ældre- og handicapområdet, revideret katalog. København: Forlaget Kommuneinformation, juni 1998.

Kommunernes Landsforening 1998b: Kontraktstyring på ældreområdet. København: Forlaget Kommuneinformation.

Kommunernes Landsforening 2003: Fælles sprog-II - De foreløbige resultater, (http:// www.kl.dk/204768 \. L 130: lov nr. 130 af 29. maj 2002 om ændring af lov om social service, lov om hjemmeservice, lov om retssikkerhed og administration på det sociale område og lov om individuel boligstøtte. 
LBK 328: Bekendtgørelse om kvalitetsstandarder m.v. for hjælp efter $\S \S 71$ og 72 i lov om social service. Socialministeriet, den 22. april 1998.

LBK 755: Bekendtgørelse af lov om social service. Lovbekendtgørelse af 9. september 2002.

Luhmann, Niklas 1987: "Staat und Politik. Zur Semantik der Selbstbeschreibung politischer Systeme", pp. 75-103 in Soziologische Aufklärung 4. Opladen: Westdeutscher Verlag.

Luhmann, Niklas 1990 [1981]: Political theory in the Welfare state. Berlin: de Gruyter.

Luhmann, Niklas 1995 [1991]: “Die Form Person“ pp. 142-154 in Soziologische Aufklärung 6. Opladen: Vestdeutscher Verlag.

Luhmann, Niklas 2000a [1984]: Sociale systemer, Grundrids til en almen teori. København: Hans Reitzels forlag.

Luhmann, Niklas 2000b: Organisation und Entscheidung. Opladen/Wiesbaden: Westdeutscher Verlag.

Luhmann, Niklas 2000c: Die Politik der Gesellschaft. Frankfurt am Main: Suhrkamp Verlag.

Luhmann, Niklas 2002 [1995]: “Inklusion og eksklusion", Distinktion, nr. 4: 121-140.

Mortensen, Nils 2004: Det paradoksale samfund. København: Hans Reitzels Forlag.

Nassehi, Armin/Gerd Nollmann 1997: “Inklusionen. Organisationssoziologische Ergänzungen der Inklusions-/Exklusionstheorie“",Soziale Systeme, Jg. 3, Heft 2: 393411.

Nordiske Organisasjonsstudier 2001: Temanummer om Niklas Luhmanns Organisationsteori, nr. 2, årg.3.

Organisation 2006: Temanummer om Luhmanns organisationsteori, vol. 13(1), London, SAGE.

Orientering om L 130, om ændring af lov om social service, lov om hjemmeservice, lov om retssikkerhed og administration på det sociale område og lov om individuel boligstøtte, den 29. maj 2002, Socialministeriet.

Regeringen 2002a: Med borgeren ved roret. Hovedpunkterne i forligene med Centralorganisationernes Fællesudvalg og Akademikernes Centralorganisation. København: Finansministeriet, maj 2002.

Regeringen 2002b: Velfærd og valgfrihed - et reformprogram. København: Finansministeriet, maj 2002.

Regeringen 2003: En mere borgernær offentlig sektor. København: Finansministeriet, november 2003.

Schultz-Larsen, Kirsten 2004: Udviklings- og forandringsprocesser i den kommunale ældrepleje. En videnskabelig undersøgelse af resultater og effekter. København: Institut for Folkesundhedsvidenskab, Københavns Universitet.

Seidl, David/Kai Helge Becker (red.) 2005: Niklas Luhmann and Organisation Studies. København: Liber \& Copenhagen Business School Press.

Socialministeriet 2002: Frit valg sætter de ældre i centrum. Pressemeddelelse den 28. februar 2002.

Stäheli, Urs 1998: Signifying Failures. A Deconstructive Reading of Niklas Luhmann's Systems Theory. Ph.D.-Thesis, University of Essex.

Sundhedsstyrelsen 1992: Kvalitetsudvikling. Hvorfor og hvordan. København: Sundhedsstyre lsen. 
Sundhedsstyrelsen 1993: National strategi for kvalitetsudvikling i sundhedsvæsenet. København: Sundhedsstyrelsen og Sundhedsministeriet.

Szebehely, Marta (red.) 2005: Äldreomsorgsforskning i Norden. En kunskapsöversikt. København: Nordiska Ministerrådet, TemaNord.

Teubner, Gunther Michael Hutter 2003 [1994]: “Homo oeconomicus og homo juridicus. Kommunikative fiktioner", pp. 248-265 in Holger Højlund/Morten Knudsen (red.), Organiseret kommunikation. Systemteoretiske analyser. København: Forlaget Samfundslitteratur.

VEJ 83: Supplement til vejledning af 6. marts 1998 om sociale tilbud til ældre m.fl. om Bekendtgørelse om kvalitetsstandarder m.v. for hjælp efter $\S \S 71$ og 72 i lov om social service. Socialministeriet, den9.juni1998.

Vejledning af 9. oktober, supplement til vejledning om sociale tilbud til ældre m.fl. efter lov om social service. Skrivelse af 9. oktober 2002, Socialministeriet.

Videnscenter på ældreområdet 2001: Ældreomsorg - management eller menneskelighed? Hellerup: Videnscenter på ældreområdet. 